Ewa Katarzyna Czech

Uniwersytet $w$ Bialymstoku

\title{
KWESTIA ISTNIENIA JEDNOZNACZNOŚCI I SPÓJNOŚCI TERMINOLOGICZNEJ NORM, W OPARCIU O KTÓRE CHRONIONE SA LASY - STUDIUM WYBRANYCH USTAW
}

\section{Wprowadzenie}

W świetle funkcjonującego w Polsce porządku prawnego lasy stanowią dobro prawne. Jednocześnie funkcje przez nie spełniane powodują, że sporne staje się widzenie ich ochrony, co najmniej w zakresie instrumentarium prawnego, zawartego w wielu aktach normatywnych, służącego realizowaniu tej ochrony. Należy mieć jednocześnie na uwadze, że istotne w zakresie ochrony środowiska są uzyskiwane efekty rozumiane jako te, które mogą przynieść tak pozytywne, jak i negatywne skutki w funkcjonowaniu ekosystemów. Ochrona poszczególnych elementów przyrodniczych nie może być rozpatrywana w oderwaniu od skutków, jakie ich funkcjonowanie wywołuje w obrębie danego ekosystemu i całego środowiska. Istotne jest również oddziaływanie jednego ekosystemu na inny ekosystem. Twierdzenia te wpisują się bez wątpienia w zasadę kompleksowości ochrony środowiska, która wyrażona została w art. 5 ustawy Prawo ochrony środowiska. ${ }^{1}$

Takie postrzeganie środowiska i efektów jego ochrony uwidacznia jednocześnie sporność sytuacji występujących w tych przypadkach, gdy dany element środowiska czy element przyrodniczy chroniony i jednocześnie wykorzystywany jest $\mathrm{w}$ oparciu o konstrukcje prawne zawarte w kilku aktach normatywnych o niejednolitym przedmiocie regulacji i celach, które w wyniku wykorzystywania norm w nich zawartych mają być zgodnie z wolą ustawodawcy osiągnięte. Na taki stan rzeczy wpływa niejednokrotnie zamęt terminologiczny istniejący $\mathrm{w}$ obszarze unormowań zawartych w aktach prawnych, interpretowanych na potrzeby rozważenia danego zagadnienia. Tak jest i w przypadku problematyki poddanej analizie w poniższych rozważaniach, tj. zamętu terminologicznego wpływającego na możliwość określenia, w jakim za- 
kresie konstrukcje zawarte w normach ustawy o lasach ${ }^{2}$ i ustawy Prawo ochrony środowiska umożliwiają ochronę lasów.

Tak określony przedmiot rozważań powinno jednak poprzedzać co najmniej określenie miejsca pojęć „,zasoby leśne” i „lasy” w obrębie rozumienia prawnego środowiska, a także elementów środowiska. Określenie miejsca lasów i zasobów leśnych w tych dwóch wymienionych kategoriach warunkowałoby udzielenie odpowiedzi o zakresie ochrony lasów i zasobów leśnych, w oparciu o konstrukcje prawne zawarte w ustawie o lasach i w ustawie Prawo ochrony środowiska. Jednocześnie dokonanie analizy tego zagadnienia pozwoli na uwidocznienie barku jednoznaczności i spójności tych pojęć wykorzystywanych przez ustawodawcę na gruncie powoływanych aktów normatywnych.

Rozważania zawarte w tym opracowaniu ograniczą się właśnie do określenia relacji wskazywanych wyżej pojęć, którymi posługuje się ustawodawca w treści norm ustawy o lasach i ustawy Prawo ochrony środowiska. Jest to podyktowane obszernością tak określonego zagadnienia i jednoczesnym szerokim zakresem drugiej ze wskazywanych problematyk, tj. zakresu ochrony lasów i zasobów leśnych, w oparciu o konstrukcje prawne zawarte w ustawie o lasach i ustawie Prawo ochrony środowiska.

\section{Prawne ujęcie środowiska i elementów środowiska}

Ustawodawca zawarł definicję legalną środowiska w treści art. 3 pkt 39 ustawy Prawo ochrony środowiska. Nie wskazano wprost zasobów leśnych czy lasów jako elementów przyrodniczych w brzmieniu tej definicji. Należy mieć jednak na uwadze, że ustawodawca posługuje się katalogiem otwartym w zakresie określenia elementów przyrodniczych, tych przekształconych, jak i nieprzekształconych w wyniku działalności człowieka. Powoduje to, że brak wymienienia w definicji legalnej środowiska, lasów czy zasobów leśnych nie może skutkować, tylko z powodu istnienia tej okoliczności prawnej, ich eliminacją z zakresu prawnego rozumienia środowiska.

Istotnym, z punktu widzenia prowadzonych rozważań, jest także pojęcie, które funkcjonuje na gruncie ustawy o lasach. Mianowicie jest nim termin „elementy środowiska", którym posłużono się przykładowo w treści art. 1 tego aktu normatywnego. Uwzględniając treść definicji legalnej środowiska, zawartej w ustawie Prawo ochrony środowiska, zgodnie z którą obok elementów przyrodniczych tworzy je również wzajemne oddziaływanie między tymi elementami, można by przyjąć, że pojęcie elementy środowiska jest pojęciem szerszym niż pojęcie elementy przyrodnicze. Przyjęcie, że są to synonimy pociągałoby za sobą jednoczesne uznanie braku racjonalności w działaniu ustawodawcy. Należy jednocześnie podkreślić, że w nauce prawa wyrażono stanowisko wskazujące na traktowanie tych dwóch powoływa- 
Kwestia istnienia jednoznaczności i spójności terminologicznej norm...

nych terminów jako synonimów, z czym nie można się zgodzić. Podniesione zostało, w zakresie komentowania zasady kompleksowości ochrony środowiska, że ochrona środowiska i jego konkretnych elementów nie może być realizowana w oderwaniu od większej całości, w której konkretny element funkcjonuje. ${ }^{3}$ Należy zauważyć, że w treści art. 5 ustawy Prawo ochrony środowiska, w której wyrażona została zasada kompleksowości ochrony środowiska, ustawodawca posługuje się pojęciem elementy przyrodnicze, a nie elementy środowiska.

\section{Ujęcie prawne zasobów leśnych i lasów w kontekście definicji legalnej środowiska i znaczenia prawnego elementów środowiska jako przykład braku jednoznaczności i spójności pojęć wykorzystywanych w normach ustawy o lasach i ustawy Prawo ochrony środowiska}

Przechodząc do rozważań w zakresie stosunku pojęcia lasy i zasoby leśne względem pojęć środowisko i elementy środowiska, należy powołać zasadny, w mojej opinii, pogląd Naczelnego Sądu Administracyjnego wyrażony w wyroku z dnia 23 kwietnia 2013 r. (I OSK 1983/11, LEX nr 1336348). Zgodnie z nim to, iż dany grunt jest traktowany jako las w znaczeniu przyrodniczym nie oznacza, że jest lasem w znaczeniu prawnym. Z pewnością jest to konsekwencją tego, że ustawodawca w ustawie o lasach zawarł definicję legalną lasów. Równocześnie kwestią otwartą jest to, czy odpowiednio pogląd ten może mieć zastosowanie do pojmowania zasobów leśnych. Różnica między rozumieniem pojęcia lasy i zasoby leśne sprowadza się do tego, że definicja tego ostatniego terminu nie została zawarta w przepisach ustawy o lasach.

W literaturze przedmiotu podnoszone jest, że jako zjawisko niekorzystne należy oceniać to, że zarówno w prawie leśnym (np. w rozporządzeniu Rady Ministrów, dotyczącym gospodarki finansowej w Lasach Państwowych), jak i w różnych opracowaniach o charakterze studialnym czy publicystycznym pojęcie ,zasoby leśne” jest używane w zróżnicowanych znaczeniach (np. jako substytut pojęcia majątku, wchodzącego w skład leśnych zasobów ekonomicznych). Uwzględniając tę okoliczność, zdaniem Autora tego stanowiska, po napotkaniu w jakimś tekście pojęcia zasoby leśne, jego znaczenie powinno być dekonspirowane indywidualnie. Zauważa on także, że z kontekstu stosowania tego pojęcia w ustawie o lasach można wywieść następującą jego definicję. Zasobami leśnymi jest zbiór roślinności leśnej, występujący w danym ekosystemie leśnym jako część składowa tego ekosystemu. ${ }^{4}$

3 K. Gruszecki, Prawo ochrony środowiska, Komentarz, Warszawa 2007, s. 345.

4 K. Tomaszewski, Prototyp Encyklopedii leśnej. Materiał niepublikowany, www.encyklopedialesna.pl, stan na dzień 7 stycznia 2015 r. 
Uwzględniając powołane stanowiska należy zauważyć, że w treści art. 1 ustawy o lasach wskazane zostało, że w tym akcie prawnym określono zasady zachowania, ochrony i powiększania zasobów leśnych, a także zasady gospodarki leśnej w powiązaniu z innymi elementami środowiska i z gospodarką narodową. Takie sformułowanie tego przepisu powoduje, że konieczne staje się odniesienie do treści art. 6 ust. 1 pkt 1 ustawy o lasach, w której zawarta została definicja gospodarki leśnej. Zgodnie z tym przepisem przez gospodarkę leśną należy rozumieć działalność leśną w zakresie urządzania, ochrony i zagospodarowania lasu, utrzymania i powiększania zasobów i upraw leśnych, gospodarowania zwierzyną, pozyskiwania - z wyjątkiem skupu - drewna, żywicy, choinek, karpiny, kory, igliwia, zwierzyny oraz płodów runa leśnego, a także sprzedaż tych produktów oraz realizację pozaprodukcyjnych funkcji lasu. Już przywołanie regulacji art. 1 i art. 6 ust. 1 pkt 1 ustawy o lasach wskazuje na mogące zaistnieć problemy definicyjne, w zakresie tego, co należy traktować jako zasoby leśne w sensie prawnym.

Przede wszystkim w treści wyżej powołanej definicji gospodarki leśnej, ustawodawca posługuje się pojęciem lasów, zasobów leśnych, upraw leśnych, ale także pojęciem zwierzyny, drewna, żywicy, choinek, karpiny, kory, igliwia czy w końcu płodów runa leśnego. Bez wątpienia terminologia zawarta w definicji legalnej gospodarki leśnej ma różny stopień szczegółowości, a część ze wskazanych tu pojęć zawiera się w innych zawartych tu terminach, o większym zakresie ogólności. Nie oznacza to jednak, że określenie, które z kategorii tu zawartych ma charakter bardziej ogólny, a które bardziej szczegółowy, jest za każdym razem oczywiste. Szczególne trudności powstają w zakresie określenia względem siebie stosunku pojęć lasy i zasoby leśne. Ma to o tyle kluczowe znaczenie, że w obrębie wskazania zakresu przedmiotowego ustawy o lasach ustawodawca posługuje się jedynie pojęciem zasoby leśne, natomiast pojęcie lasu nie występuje w treści art. 1. Co znaczące praktyka stosowania prawa mogłaby wskazywać, że pojęcie lasy i zasoby leśne należy traktować jako synonimy, ewentualnie lasy zawierają się w szerszym treściowo pojęciu zasoby leśne. Potwierdzenia takiego stanu rzeczy można by upatrywać w stanowisku Sądu Najwyższego, zawartym w postanowieniu z dnia 20 września 2012 r. (IV CSK 41/12, LEX nr 1232472). W orzeczeniu tym, określił on, opierając się na brzmieniu art. 1 ustawy o lasach, że przepisy tego aktu normatywnego mają na celu właśnie zachowanie lasów, ich ochronę oraz powiększanie zasobów leśnych.

Jednocześnie w treści art. 1 ustawy o lasach wskazano, że określone w tym akcie normatywnym zostały m.in. zasady zachowania, ochrony i powiększania zasobów leśnych w powiązaniu $\mathrm{z}$ innymi elementami środowiska. $Z$ uwagi na to treść art. 1 ustawy o lasach, pozwala na sformułowanie wniosku, że zasoby leśne stanowią element środowiska. Natomiast usytuowanie pojęcia zasoby leśne w znaczeniu prawnym środowiska, a konkretnie relacji terminu zasoby leśne do pojęcia zasoby przyrodnicze, z uwagi na brak definicji legalnej zasobów leśnych, jest uwarunkowane dalszym określeniem relacji tego pojęcia do znaczenia prawnego lasów. Jedno- 
cześnie konieczne jest usytuowanie pojęcia lasy w zakresie treściowym środowiska czy elementów środowiska. To z kolei wymaga odniesienia się do definicji legalnej lasów, zawartej w art. 3 ustawy o lasach.

Zgodnie z tą normą lasem jest grunt o zwartej powierzchni co najmniej 0,10 ha, pokryty roślinnością leśną (uprawami leśnymi) - drzewami i krzewami oraz runem leśnym - lub przejściowo jej pozbawiony: przeznaczony do produkcji leśnej lub stanowiący rezerwat przyrody lub wchodzący w skład parku narodowego albo wpisany do rejestru zabytków; jak również grunt związany z gospodarką leśną, zajęty pod wykorzystywane dla potrzeb gospodarki leśnej: budynki i budowle, urządzenia melioracji wodnych, linie podziału przestrzennego lasu, drogi leśne, tereny pod liniami energetycznymi, szkółki leśne, miejsca składowania drewna, a także wykorzystywany na parkingi leśne i urządzenia turystyczne. Uwagę zwraca brak posługiwania się w powołanej definicji legalnej lasów pojęciem zasoby leśne. Z kolei w definicji trwale zrównoważonej gospodarki leśnej ustawodawca wykorzystuje pojęcie lasy i również nie posługuje się terminem zasoby leśne. Natomiast w definicji gospodarki leśnej wykorzystuje oba pojęcia. Należy jeszcze raz podkreślić, że ustawodawca nie definiuje w przepisach ustawy o lasach pojęcia „zasoby leśne”.

Jednocześnie treść art. 6 ust. 1 pkt 1 ustawy o lasach może być odczytywana również w ten sposób, że pojęcie zasoby leśne ma charakter węższy w odniesieniu do znaczenia terminu lasy. W treści art. 6 ust. 1 pkt 1 ustawodawca rozróżnia kategorię zasobów leśnych i upraw leśnych w taki sposób, że za co najmniej utrudnione należy przyjąć traktowanie któregokolwiek z tych terminów jako pojęcia nadrzędnego względem drugiego z nich. Równocześnie wskazane w tym przepisie zostało, że gospodarka leśna to działalność leśna w zakresie urządzania, ochrony i zagospodarowania lasu, a nie w zakresie urządzania, ochrony i zagospodarowania zasobów leśnych. W ramach tej gospodarki ma mieć miejsce m.in. utrzymanie i powiększanie zasobów leśnych. Gdyby na gruncie tej normy ustawodawca przyjmował, że pojęcie zasoby leśne ma zakres szerszy niż lasy, nie do końca zrozumiałe byłoby wyróżnianie, że w ramach tej gospodarki ma być realizowane utrzymanie zasobów leśnych. Taka redakcja tego przepisu wskazywałaby raczej na istniejącą odrębność między pojęciem lasy i zasoby leśne. Mając świadomość kontrowersyjności stanowiska wskazującego na odrębność względem siebie pojęć zasoby leśne i lasy, pragnę podkreślić, że może ono znaleźć swe uzasadnienie na gruncie treści art. 6 ust. 1 pkt 1 ustawy o lasach. W świetle obecnego, a także proponowanego przeze mnie brzmienia art. 1 ustawy o lasach, należy uznać możliwość istnienia takiego poglądu za niepożądaną.

Natomiast w przypadku przyjęcia, że zasoby leśne są pojęciem węższym niż zakres treściowy definicji lasy, to należy zwrócić uwagę na następującą kwestię redakcyjną na gruncie art. 6 ust. 1 pkt 1 ustawy o lasach. W zakres ochrony danego dobra prawnego wchodzi przecież zawsze co najmniej jego utrzymanie. Skoro zatem chronione, w tym utrzymywane mają być lasy, to np. zapis o utrzymywaniu zasobów 
leśnych należałoby traktować jako zbędny. Jednocześnie redakcja treści art. 6 ust. 1 pkt 1 ustawy o lasach nie pozwala również na przyjęcie, że termin zasoby leśne jest pojęciem szerszym w stosunku do terminu lasy. Z kolei ten wniosek znajduje swe uzasadnienie w tym, że gdyby pojęcie zasoby leśne miało charakter szerszy od pojęcia lasy, brzmienie art. 6 ust. 1 pkt 1 ustawy o lasach powinno przybrać następujący kształt: „gospodarka leśna - działalność leśna w zakresie urządzania, ochrony i zagospodarowania lasu, utrzymania i powiększania zasobów leśnych innych niż lasy i upraw leśnych, gospodarowania zwierzyną, pozyskiwania - z wyjątkiem skupu - drewna, żywicy, choinek, karpiny, kory, igliwia, zwierzyny oraz płodów runa leśnego, a także sprzedaż tych produktów oraz realizacja pozaprodukcyjnych funkcji lasu".

Należy też podkreślić, że za traktowaniem zasobów leśnych jako terminu węższego w stosunku do pojęcia lasy przemawia także wyżej powołane stanowisko przedstawiciela nauk pozaprawnych, w którym termin zasoby leśne ograniczony został do zbioru roślinności leśnej, występującego w danym ekosystemie leśnym jako część składowa tego ekosystemu. Zatem przykładowo część definicji pojęcia las, zawarta $\mathrm{w}$ art. 3 tego aktu normatywnego, w którym nakazuje się jego rozumienie jako grunt związany z gospodarką leśną, zajęty pod wykorzystywane dla potrzeb gospodarki leśnej: budynki i budowle, urządzenia melioracji wodnych, linie podziału przestrzennego lasu, drogi leśne, tereny pod liniami energetycznymi, szkółki leśne, miejsca składowania drewna, a także wykorzystywany na parkingi leśne i urządzenia turystyczne, nie zawiera się w sposób oczywisty i całościowy w pojęciu zasoby leśne rozumianym w powoływanym ostatnio znaczeniu.

Równocześnie określenie zakresu treściowego pojęcia zasoby leśne, jako węższego w stosunku do pojęcia lasy, może pozwolić na sformułowanie wniosku o braku jednoznacznej spójności pomiędzy przedmiotem regulacji ustawy o lasach, określonym $\mathrm{w}$ art. 1 tej ustawy, w stosunku do faktycznego przedmiotu regulacji, wynikającego $\mathrm{z}$ treści przepisów tam zawartych. Zatem uwzględniając brzmienie definicji ustawowej trwale zrównoważonej gospodarki leśnej, należałoby uznać, że jej uregulowanie w tym akcie normatywnym, w obszarze innym niż dotyczący zasobów leśnych, przekracza zakres przedmiotu regulacji określony w art. 1 ustawy o lasach. Brak definicji legalnej zasobów leśnych i możliwy do określenia stosunek tego pojęcia do terminu lasy, wywołuje, w mojej opinii, konieczność sformułowania wniosku de lege ferenda $\mathrm{w}$ kierunku zmiany zapisów powoływanego art. 1 nadającej mu brzmienie: „Ustawa określa zasady zachowania, ochrony i powiększania lasów oraz zasady gospodarki leśnej w powiązaniu z innymi elementami środowiska i z gospodarką narodową". Takie brzmienie art. 1 powodowałoby większą spójność przykładowo z brzemieniem art. 6 ust. 1 pkt 1 i pkt 2 ustawy o lasach. Całe zagadnienie jest jednak o tyle problematyczne, że obecne brzmienie art. 1 ustawy o lasach nakazywałoby przyjmowanie stosunku odwrotnego w zakresie relacji pojęć zasoby leśne i lasy, tj., że pojęcie zasoby leśne jest pojęciem szerszym do pojęcia lasy. W innym 
wypadku, co już było wskazywane, część przepisów ustawy znalazłaby się poza przedmiotem jej regulacji. Taka relacja tych dwóch pojęć, w świetle dalszych norm tego aktu normatywnego, jest jednak w mojej opinii co najmniej sporna.

Wskazywane zmiany legislacyjne są konieczne celem osiągnięcia jednolitości interpretacyjnej w omawianym zakresie. Jednocześnie są one zasadne w przypadku przyjęcia, że zasoby leśne są pojęciem węższym od znaczenia lasu w sensie prawnym.

Rozważając definicję legalną lasów, w kategoriach traktowania lasów jako środowiska, konieczne są także następujące refleksje. Pierwsza z nich, prima facie mogłaby wpływać na możliwość postrzegania lasów w kategoriach środowiska. Zgodnie z tą definicją, co już było wskazywane, lasem jest również grunt związany z gospodarką leśną, zajęty pod wykorzystywane dla potrzeb gospodarki leśnej: budynki i budowle, urządzenia melioracji wodnych, linie podziału przestrzennego lasu, drogi leśne, tereny pod liniami energetycznymi, szkółki leśne, miejsca składowania drewna, a także wykorzystywany na parkingi leśne i urządzenia turystyczne. Za co najmniej problematyczną kwestię można by uznać możliwość taktowania w kategoriach elementu przyrodniczego, gruntu zajętego pod budynki i budowle, urządzenia melioracji wodnych, nawet gdy są one wykorzystywane dla potrzeb gospodarki leśnej. Mimo takiego zajęcia grunt nie traci swej cechy, tj. tworzenia powierzchni ziemi, a tym samym nie przestaje być składnikiem elementu przyrodniczego, tj. powierzchni ziemi. W tym wypadku grunt ten, będący sam w sobie składnikiem elementu przyrodniczego, traktowany jest tu jako las, z uwagi na to, że jest on związany z gospodarką leśną i zajęty zgodnie z uwarunkowaniami zawartymi w powoływanej definicji legalnej.

Należy jednocześnie zauważyć, że zgodnie ze znaczeniem definicji lasu określonym przez ustawodawcę w powoływanym art. 3, zawsze jest nim grunt. O tym, że ma on być traktowany jako las w znaczeniu prawnym decyduje spełnienie wymogów ustawowych przewidzianych w treści powołanego artykułu. Jak słusznie zauważone zostało w nauce prawa, samego pojęcia las nie należy utożsamiać z pojęciem nieruchomość gruntowa. Jest tak pomimo tego, że jak zauważa Autor tego stanowiska, punktem wyjścia jest wskazanie przez prawodawcę, że las jest gruntem. ${ }^{5}$ Dalej jako wzmocnienie swej argumentacji przywołuje on pogląd wyrażony w doktrynie prawa cywilnego. Zgodnie z tym ostatnim, podstawowym elementem definicji lasu jest odwołanie się przez ustawodawcę do pojęcia grunt. Dalej wskazane zostało, że pojęcie to powinno być odróżniane od pojęcia nieruchomość. Grunt należy bowiem rozumieć jako fragment powierzchni ziemi w znaczeniu trójwymiarowym, który stanowi przedmiot określonych stosunków prawnych bądź to prawa prywatnego, bądź to prawa publicznego. ${ }^{6}$ Zatem należy przyjmować, w świetle tak sformułowanego 
poglądu, że posłużenie się przez ustawodawcę pojęciem grunt w definicji ustawowej lasów powoduje możliwość jego funkcjonowania tak na gruncie stosunków prawa publicznego, jak i prywatnego, nie ograniczając możliwości jego funkcjonowania do żadnej z kategorii tych stosunków prawnych.

Istotna jest również kolejna uwaga dotycząca definicji legalnej lasów. W samej definicji ustawowej lasów, jak już wskazywałam, określone zostało, że są nimi również grunty o zwartej powierzchni co najmniej 0,10 ha, pokryte roślinnością leśną (uprawami leśnymi) - drzewami i krzewami oraz runem leśnym - lub przejściowo jej pozbawione przeznaczone do produkcji leśnej lub stanowiące rezerwat przyrody lub wchodzące w skład parku narodowego. Uwagę zwraca samo już użycie spójnika „lub”, który zgodnie z zasadami logiki prawniczej wskazuje, że grunty te mogą zostać przeznaczone do produkcji leśnej i stanowić rezerwat przyrody oraz jednocześnie wchodzić w skład parku narodowego. Jak zasadnie zauważono w nauce prawa, w ustawie o lasach wprowadzono cztery kryteria uznawania danego gruntu za las. Zgodnie z dalszą wypowiedzią Autora tego stanowiska, z czym należy się zgodzić, trzecim kryterium jest kryterium przeznaczenia - do produkcji leśnej, chyba że mamy do czynienia $z$ lasami w rezerwatach przyrody i w parkach narodowych bądź lasami wpisanymi do rejestru zabytków, które z istoty swej nie są przeznaczone do produkcji leśnej.?

Tak określony problem interpretacyjny powinien, w mojej opinii, powodować posługiwanie się w zakresie określenia pojęcia las spójnikiem albo, w odniesieniu do gruntów stanowiących rezerwaty przyrody czy wchodzących w skład parku narodowego. Uzasadnienia takiego stanu rzeczy należy także poszukiwać w brzmieniu art. 7 ust. 2 ustawy o lasach. W jego treści ustawodawca wprost wskazuje, że gospodarka leśna w lasach stanowiących rezerwaty przyrody oraz wchodzących w skład parków narodowych powinna uwzględniać zasady określone w przepisach o ochronie przyrody. Jednocześnie ustawodawca posługuje się spójnikiem „albo” w zakresie gruntów o zwartej powierzchni co najmniej 0,10 ha, pokrytych roślinnością leśną (uprawami leśnymi) - drzewami i krzewami oraz runem leśnym - lub przejściowo jej pozbawionych, wpisanych do rejestru zabytków. Posłużenie się taką konstrukcją normatywną wskazuje, że w zakresie tych ostatnich gruntów nie mogą być one przeznaczone do produkcji leśnej lub stanowić rezerwatów przyrody lub wchodzić w skład parku narodowego.

\section{Podsumowanie}

Powołane wyżej unormowania wskazują na wielość i nie zawsze istniejącą jednoznaczność nomenklatury, którą posługuje się ustawodawca na gruncie ustawy o lasach i ustawy Prawo ochrony środowiska. Jednocześnie problemy interpre- 
tacyjne nasila brak zdefiniowania części pojęć, wykorzystywanych przez ustawodawcę, w zakresie których należy uznać ich niewystarczające rozumienie w języku potocznym. Taki stan rzeczy wpływa nie tylko na istnienie braku jednoznaczności, ale także spójności terminów, którymi posłużono się na gruncie norm obu powoływanych aktów normatywnych.

W świetle zawartych wyżej rozważań należy przyjąć, że zasoby leśne są elementem środowiska. Wskazuje na to treść art. 1 ustawy o lasach. Lasy są natomiast składnikiem elementu przyrodniczego, z uwagi na to, że są to grunty tworzące powierzchnię ziemi. Jest tak pomimo tego, że grunty te, aby były traktowane jako lasy, muszą spełnić przesłanki określone $\mathrm{w}$ art. 3 ustawy o lasach. $\mathrm{Z}$ uwagi na to lasy muszą być postrzegane jako środowisko w sensie prawnym, skoro tworzy je m.in. ogół elementów przyrodniczych zarówno nieprzekształconych, jak i przekształconych w wyniku działalności człowieka.

Z kolei brak definicji legalnej zasobów leśnych uniemożliwia w mojej opinii jednoznaczne określenie relacji tego pojęcia do terminu lasy. Jednocześnie brak tej definicji niweluje możliwość jednoznacznego określenia stosunku tego pojęcia w odniesieniu do terminu elementy przyrodnicze. Przyjęcie jednak, że pojęcie elementy środowiska ma charakter szerszy niż termin elementy przyrodnicze, nie może powodować wykluczenia zasobów leśnych z rozumienia prawnego środowiska. Jest to spowodowane co najmniej tym, że treściowo termin elementy przyrodnicze zwiera się w szerszym treściowo pojęciu elementy środowiska. Również w świetle powołanego stanowiska przedstawiciela nauk pozaprawnych trudno nie traktować zasobów środowiska jako środowiska w sensie prawnym.

Choć przedstawione problemy nie wyczerpują całości zagadnienia w zakresie wpływu chaosu terminologicznego na możliwość rzetelnego określeni zakresu ochrony prawnej odnoszącej się do lasów na gruncie dwóch analizowanych ustaw, to z pewnością pozwalają one na sformułowanie następującego wniosku. Brak koniecznych zmian legislacyjnych umożliwiających usytuowanie względem siebie powołanych wyżej pojęć, uniemożliwia w mojej opinii określenie stosunku do siebie zakresów ochrony przysługującej lasom jako dobru prawnemu, na gruncie tych aktów normatywnych. Nie należy przyjmować, że w obrębie tych pojęć wystarczające jest ich rozumienie w języku potocznym. Natomiast w przypadku uznania, że konieczne jest tu uwzględnianie, nierzadko rozbieżnych, stanowisk nauk pozaprawnych (a tak jest w mojej opinii), należy przyjąć zasadność przeprowadzenia prac legislacyjnych, obejmujących również rozważenie konieczności wprowadzenia do porządku prawnego dalszych definicji legalnych, w tym definicji legalnej zasobów leśnych do ustawy o lasach. Jest to konieczne co najmniej celem zapewnienia większej spójności działań podmiotów uczestniczących w ochronie lasów. 


\section{THE ISSUES OF TERMINOLOGICAL EXPLICITNESS AND CONSISTENCY OF NORMS ON THE BASIS OF WHICH FORESTS ARE PROTECTED - STUDY OF SELECTED ACTS}

The forests are the part of the environment, which is protected as well as used, on the basis of legal structures in several normative acts with various subjects of regulation and purposes, which, as a result of the use of the standards contained therein, are to be reached in accordance with the will of the legislator. Taking into account this fact, in the considerations set out below, there will be analyzed the terminological confusion issues that affect the ability to determine to what extent the structures contained in the standards of the Forest Act and the Environmental Law Act, allow the protection of forests. The remarks contained in this paper are limited to determining the relative concepts of forests and forest resources in relation to the terms of the environment and the elements of the environment. It is justified by the amount of a given issue and at the same time by a wide range of other indicated fields, such as the scope of protection of forests and forest resources, based on legal structures in the Forest Act and the Environmental Law Act.

Keywords: terminological explicitness, norms, forests protection 